\title{
Porrhomma borgesi
}

\author{
Assessment by: Borges, P.A.V. \& Cardoso, P.
}

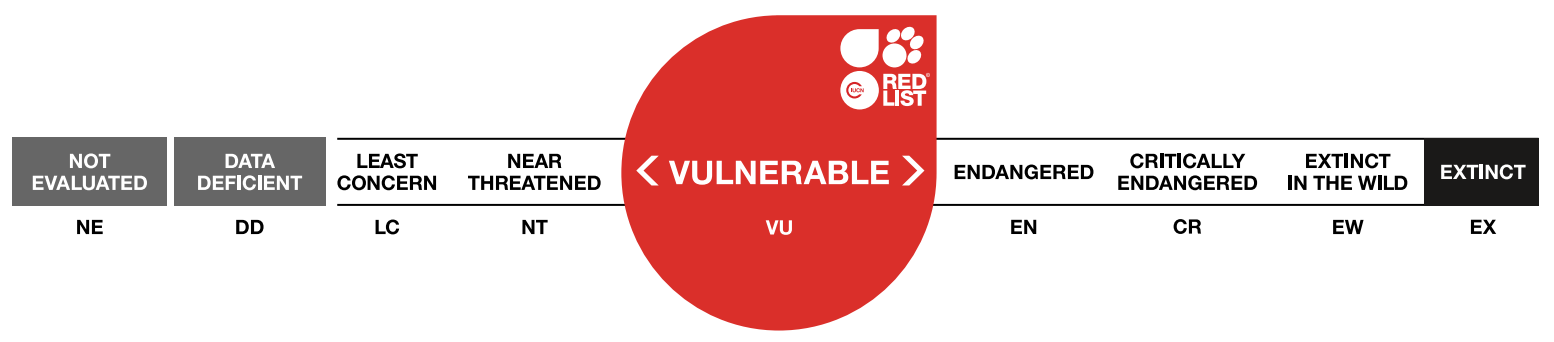

View on www.iucnredlist.org

Citation: Borges, P.A.V. \& Cardoso, P. 2020. Porrhomma borgesi. The IUCN Red List of Threatened Species 2020: e.T58080119A58080730. https://dx.doi.org/10.2305/IUCN.UK.20203.RLTS.T58080119A58080730.en

Copyright: (C 2020 International Union for Conservation of Nature and Natural Resources Reproduction of this publication for educational or other non-commercial purposes is authorized without prior written permission from the copyright holder provided the source is fully acknowledged.

Reproduction of this publication for resale, reposting or other commercial purposes is prohibited without prior written permission from the copyright holder. For further details see Terms of Use.

The IUCN Red List of Threatened Species ${ }^{T M}$ is produced and managed by the IUCN Global Species Programme, the IUCN Species Survival Commission (SSC) and The IUCN Red List Partnership. The IUCN Red List Partners are: Arizona State University; BirdLife International; Botanic Gardens Conservation International; Conservation International; NatureServe; Royal Botanic Gardens, Kew; Sapienza University of Rome; Texas A\&M University; and Zoological Society of London.

If you see any errors or have any questions or suggestions on what is shown in this document, please provide us with feedback so that we can correct or extend the information provided. 


\section{Taxonomy}

\begin{tabular}{|c|c|c|c|c|}
\hline Kingdom & Phylum & Class & Order & Family \\
\hline Animalia & Arthropoda & Arachnida & Araneae & Linyphiidae \\
\hline
\end{tabular}

Scientific Name: Porrhomma borgesi Wunderlich, 2008

\section{Taxonomic Source(s):}

Platnick, N.I. 2014. The World Spider Catalog, Version 14.5. P. Merrett \& H.D. Cameron (eds). American Museum of Natural History. Available at: http://research.amnh.org/iz/spiders/catalog/index.html. (Accessed: 31 March 2014).

Borges, P.A.V. and Wunderlich, J. 2008. Spider biodiversity patterns and their conservation in the Azorean archipelago, with descriptions of new species. Systematics and Biodiversity 6(2): 249-282.

\section{Assessment Information}

Red List Category \& Criteria: Vulnerable B1ab(i,ii,iii,iv,v)+2ab(i,ii,iii,iv, v) ver 3.1

Year Published: 2020

Date Assessed: $\quad$ October 18, 2017

\section{Justification:}

Porrhomma borgesi is an endemic money spider species occurring on three islands of the Azorean archipelago: Pico, Terceira and S. Miguel (Azores, Portugal) (Borges et al. 2010). It has a small Extent of Occurrence $\left(E O O=c a .8,312-8,500 \mathrm{~km}^{2}\right)$ and a very small area of occupancy $\left(A O O=72-124 \mathrm{~km}^{2}\right)$. The species is only abundant in very pristine sites (e.g. sites with a high habitat quality index sensu Gaspar et al. 2011) and is rare in most sites. Currently, invasive plants (Hedychium gardnerianum and Pittosporum undulatum) are impacting some of the areas and decreasing the quality of the habitat. Based on Ferreira et al. (2016) the habitat will further decline as a consequence of climate change. Therefore, we suggest as future measures of conservation: (1) regular monitoring of the species; and (2) control of invasive species namely Hedychium gardnerianum. Based upon the inferred decline in AOO, the decline in the quality and structure of habitat in some islands and number of locations the species is assessed as Vulnerable (VU).

\section{Geographic Range}

\section{Range Description:}

Porrhomma borgesi is an endemic money spider species occurring on three islands of the Azorean archipelago: Pico, Terceira and S. Miguel (Azores, Portugal) (Borges et al. 2010). Within these three islands it is known from eight Natural Forest Reserves: Mistério da Prainha, Caveiro and Caiado (Natural Park of Pico); Biscoito da Ferraria, Pico Galhardo, Caldeira Sta. Bárbara e Mistérios Negros and Terra Brava (Natural Park of Terceira); Gallhardo (Natural Park of S. Miguel). The Extent of Occurrence (EOO) is ca. $8,312-8,500 \mathrm{~km}^{2}$ and the estimated Area of Occupancy (AOO) is $72-124 \mathrm{~km}^{2}$.

\section{Country Occurrence:}


Native, Extant (resident): Portugal (Azores) 


\section{Distribution Map}

Ponta ILHADE.
Delgada SAO MIGUEL

Legend

EXTANT (RESIDENT)

POSSIBLY EXTANT (RESIDENT)
$035 m_{\text {LRECIRA }} \begin{aligned} & \text { Praia da } \\ & \text { Vitória }\end{aligned}$

Angra do
Heroismo

Heroismo

Horta

Madalena

Compiled by:

Azorean Biodiversity Group 2018
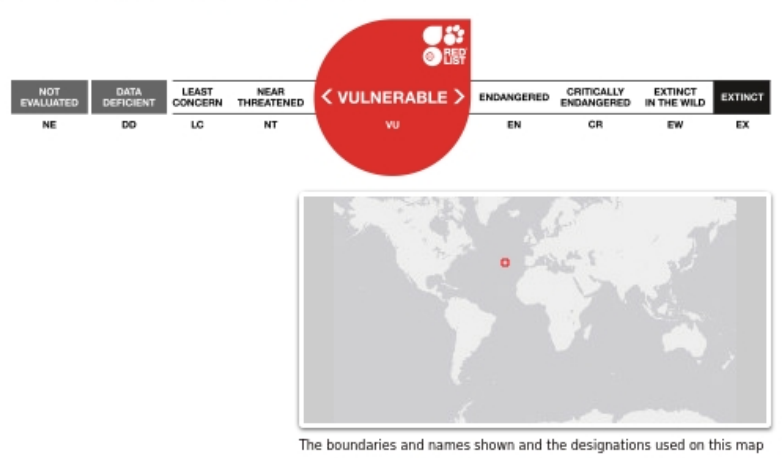

The boundahes and names shown and the designations used on this map 


\section{Population}

The species is only abundant in very pristine sites (e.g. sites with a high habitat quality index sensu Gaspar et al. 2011) and rare in most sites. Despite the fact that Porrhomma borgesi has recorded between 352 and 1,051 m in elevation, the species is particularly abundant only between 700 and 1,051 m. Many of the known sites are currently being invaded by invasive plants (e.g. Hedychium gardnerianum, Pittosporum undulatum); and a continuing decline in the number of mature individuals is estimated from monitoring schemes (Borges et al. 2016) and from the ongoing habitat degradation.

Current Population Trend: Decreasing

\section{Habitat and Ecology (see Appendix for additional information)}

Despite the fact that this species was recorded between 352 and 1,051 m elevation, Porrhomma borgesi is particularly abundant only between 700 and 1,051 m in very pristine sites (see Gaspar et al. 2011). This species builds its typical sheet-webs at ground level, usually using small holes in places with high humidity in dense forest.

Systems: Terrestrial

\section{Threats (see Appendix for additional information)}

In the past, the species has probably strongly declined due to changes in habitat size and quality (Triantis et al. 2010). Currently, the rapid advance and expansion of invasive plants species is the major threat, particularly Hedychium gardnerianum but also Pittosporum undulatum, which are changing the structure of the forest and the cover of bryophytes and ferns in the soil, which impacts the species' habitat quality. Based on Ferreira et al. (2016) the habitat will further decline as a consequence of climate change (increasing number of droughts, and habitat shifting and alteration).

\section{Conservation Actions (see Appendix for additional information)}

The species is not protected by regional law, but its habitat is in regionally protected areas (Natural Parks of Pico, Terceira and S. Miguel). Degraded areas, degraded due to invasive plant species, should be restored and a strategy needs to be developed to address the current threat posed by invasive species as well as the future threat of climate change. Formal education and awareness are needed to allow future investments in restored habitats invaded by invasive plants; while further research is needed into its ecology and life history in order to find additional specimens in other areas of native or exotic forest and to obtain adequate information on population size, distribution and trends. An areabased management plan is also necessary for the most disturbed sites including invertebrate monitoring to contribute to a potential species recovery plan. Monitoring every ten years using the BALA protocol will inform about habitat quality (see e.g. Gaspar et al. 2011).

\section{Credits}

Assessor(s): $\quad$ Borges, P.A.V. \& Cardoso, P.

Reviewer(s): $\quad$ Russell, N.

Contributor(s): $\quad$ Lamelas-López, L. \& Mendonca, E. 
Authority/Authorities: IUCN SSC Spider and Scorpion Specialist Group 


\section{Bibliography}

Borges, P.A.V., Costa, A., Cunha, R., Gabriel, R., Gonçalves, V., Martins, A.F., Melo, I., Parente, M., Raposeiro, P., Rodrigues, P., Santos, R.S., Silva, L., Vieira, P. and Vieira, V. 2010. A list of the terrestrial and marine biota from the Azores. Princípia, Cascais.

Borges, P.A.V., Gaspar, C., Crespo, L., Rigal, F., Cardoso, P., Pereira, F., Rego, C., Amorim, I.R., Melo, C., Aguiar, C., André, G., Mendonça, E., Ribeiro, S.P., Hortal, J., Santos, A.M., Barcelos, L., Enghoff, H., Mahnert, V., Pita, M.T., Ribes, J., Baz, A., Sousa, A.B., Vieira, V., Wunderlich, J., Parmakelis, A., Whittaker, R.A., Quartau, J.A., Serrano, A.R.M. \& Triantis, K.A. 2016. New records and detailed distribution and abundance of selected arthropod species collected between 1999 and 2011 in Azorean native forests. Biodiversity Data Journal 4(e10948): 1-84.

Ferreira, M.T., Cardoso, P., Borges, P.A.V., Gabriel, R., Azevedo, E.B., Reis, F., Araújo, M.B. and Elias, R.B. 2016. Effects of climate change on the distribution of indigenous species in oceanic islands (Azores). Climate Change 138(3-4): 603-615.

Gaspar, C., Gaston, K.J., Borges, P.A.V. and Cardoso, P. 2011. Selection of priority areas for arthropod conservation in the Azores archipelago. Journal of Insect Conservation 15: 671-684.

IUCN. 2020. The IUCN Red List of Threatened Species. Version 2020-3. Available at: www.iucnredlist.org. (Accessed: 10 December 2020).

Triantis, K.A., Borges, P.A.V., Ladle, R.J., Hortal, J., Cardoso, P., Gaspar, C., Dinis, F., Mendonça, E., Silveira, L.M.A., Gabriel, R., Melo, C., Santos, A.M.C., Amorim, I.R., Ribeiro, S.P., Serrano, A.R.M., Quartau, J.A. and Whittaker, R.J. 2010. Extinction debt on oceanic islands. Ecography 33(2): 285-294.

\section{Citation}

Borges, P.A.V. \& Cardoso, P. 2020. Porrhomma borgesi. The IUCN Red List of Threatened Species 2020: e.T58080119A58080730. https://dx.doi.org/10.2305/IUCN.UK.2020-3.RLTS.T58080119A58080730.en

\section{Disclaimer}

To make use of this information, please check the Terms of Use.

\section{External Resources}

For Supplementary Material, and for Images and External Links to Additional Information, please see the Red List website. 


\section{Appendix}

\section{Habitats}

(http://www.iucnredlist.org/technical-documents/classification-schemes)

\begin{tabular}{|c|c|c|c|}
\hline Habitat & Season & Suitability & $\begin{array}{l}\text { Major } \\
\text { Importance? }\end{array}$ \\
\hline 1. Forest $->1.4$. Forest - Temperate & Resident & Suitable & Yes \\
\hline
\end{tabular}

\section{Threats}

(http://www.iucnredlist.org/technical-documents/classification-schemes)

\begin{tabular}{|c|c|c|c|c|}
\hline Threat & Timing & Scope & Severity & Impact Score \\
\hline \multirow{6}{*}{$\begin{array}{l}\text { 8. Invasive and other problematic species, genes \& } \\
\text { diseases }->8.1 \text {. Invasive non-native/alien } \\
\text { species/diseases }->8.1 .2 \text {. Named species } \\
\text { (Hedychium gardnerianum) }\end{array}$} & Ongoing & $\begin{array}{l}\text { Majority (50- } \\
90 \%)\end{array}$ & Rapid declines & $\begin{array}{l}\text { Medium } \\
\text { impact: } 7\end{array}$ \\
\hline & Stresses: & \multirow{5}{*}{\multicolumn{3}{|c|}{$\begin{array}{l}\text { 1. Ecosystem stresses }->1.1 \text {. Ecosystem conversion } \\
\text { 1. Ecosystem stresses }->1.2 \text {. Ecosystem degradation } \\
\text { 1. Ecosystem stresses }->1.3 \text {. Indirect ecosystem effects } \\
\text { 2. Species Stresses }->2.1 \text {. Species mortality } \\
\text { 2. Species Stresses }->\text { 2.2. Species disturbance } \\
\end{array}$}} \\
\hline & & & & \\
\hline & & & & \\
\hline & & & & \\
\hline & & & & \\
\hline \multirow{6}{*}{$\begin{array}{l}\text { 8. Invasive and other problematic species, genes \& } \\
\text { diseases }->8.1 \text {. Invasive non-native/alien } \\
\text { species/diseases }->8.1 .2 \text {. Named species } \\
\text { (Pittosporum undulatum) }\end{array}$} & Ongoing & Minority (50\%) & Rapid declines & $\begin{array}{l}\text { Medium } \\
\text { impact: } 6\end{array}$ \\
\hline & Stresses: & \multirow{5}{*}{\multicolumn{3}{|c|}{$\begin{array}{l}\text { 1. Ecosystem stresses }->1.1 \text {. Ecosystem conversion } \\
\text { 1. Ecosystem stresses }->1.2 \text {. Ecosystem degradation } \\
\text { 1. Ecosystem stresses }->1.3 \text {. Indirect ecosystem effects } \\
\text { 2. Species Stresses }->2.1 \text {. Species mortality } \\
\text { 2. Species Stresses }->\text { 2.2. Species disturbance }\end{array}$}} \\
\hline & & & & \\
\hline & & & & \\
\hline & & & & \\
\hline & & & & \\
\hline \multirow[t]{5}{*}{$\begin{array}{l}\text { 11. Climate change \& severe weather }->11.1 \text {. Habitat } \\
\text { shifting \& alteration }\end{array}$} & Future & Whole (>90\%) & $\begin{array}{l}\text { Slow, significant } \\
\text { declines }\end{array}$ & Low impact: 5 \\
\hline & Stresses: & \multirow{4}{*}{\multicolumn{3}{|c|}{$\begin{array}{l}\text { 1. Ecosystem stresses } \rightarrow 1.2 \text {. Ecosystem degradation } \\
\text { 1. Ecosystem stresses }->1.3 \text {. Indirect ecosystem effects } \\
\text { 2. Species Stresses }->2.1 \text {. Species mortality } \\
\text { 2. Species Stresses }->2.2 \text {. Species disturbance }\end{array}$}} \\
\hline & & & & \\
\hline & & & & \\
\hline & & & & \\
\hline \multirow[t]{4}{*}{$\begin{array}{l}\text { 11. Climate change \& severe weather -> 11.2. } \\
\text { Droughts }\end{array}$} & Future & Whole (>90\%) & Rapid declines & $\begin{array}{l}\text { Medium } \\
\text { impact: } 6\end{array}$ \\
\hline & Stresses: & \multicolumn{3}{|c|}{ 1. Ecosystem stresses $->1.2$. Ecosystem degradation } \\
\hline & & \multicolumn{3}{|c|}{ 2. Species Stresses -> 2.1. Species mortality } \\
\hline & & \multicolumn{3}{|c|}{ 2. Species Stresses $->$ 2.2. Species disturbance } \\
\hline
\end{tabular}

\section{Conservation Actions in Place}

(http://www.iucnredlist.org/technical-documents/classification-schemes) 


\begin{tabular}{|l|}
\hline Conservation Action in Place \\
\hline In-place research and monitoring \\
\hline Action Recovery Plan: No \\
\hline Systematic monitoring scheme: No \\
\hline In-place land/water protection \\
\hline Conservation sites identified: Yes, over entire range \\
\hline Percentage of population protected by PAs: $91-100$ \\
\hline Area based regional management plan: No \\
\hline Occurs in at least one protected area: Yes \\
\hline
\end{tabular}

\section{Conservation Actions Needed}

\section{(http://www.iucnredlist.org/technical-documents/classification-schemes)}

\section{Conservation Action Needed}

1. Land/water protection $->1.1$. Site/area protection

2. Land/water management -> 2.1. Site/area management

2. Land/water management -> 2.2. Invasive/problematic species control

2. Land/water management -> 2.3. Habitat \& natural process restoration

4. Education \& awareness $->4$.1. Formal education

5. Law \& policy -> 5.4. Compliance and enforcement -> 5.4.3. Sub-national level

\section{Research Needed}

(http://www.iucnredlist.org/technical-documents/classification-schemes)

\section{Research Needed}

1. Research $->1.2$. Population size, distribution $\&$ trends

1. Research -> 1.3. Life history \& ecology

1. Research $->1.5$. Threats

2. Conservation Planning -> 2.2. Area-based Management Plan

3. Monitoring $->$ 3.1. Population trends

3. Monitoring $->$ 3.4. Habitat trends

\section{Additional Data Fields}




\section{Distribution}

Estimated area of occupancy (AOO) $\left(\mathrm{km}^{2}\right):$ : 72-124

Continuing decline in area of occupancy (AOO): Yes

Extreme fluctuations in area of occupancy (AOO): Unknown

Estimated extent of occurrence (EOO) $\left(\mathrm{km}^{2}\right): 8312-8500$

Continuing decline in extent of occurrence (EOO): Yes

Extreme fluctuations in extent of occurrence (EOO): No

Number of Locations: 8

Continuing decline in number of locations: Yes

Extreme fluctuations in the number of locations: No

Lower elevation limit (m): 352

Upper elevation limit (m): 1,051

\section{Population}

Continuing decline of mature individuals: Yes

Population severely fragmented: No

Habitats and Ecology

Continuing decline in area, extent and/or quality of habitat: Yes

Generation Length (years): 1 


\section{The IUCN Red List Partnership}

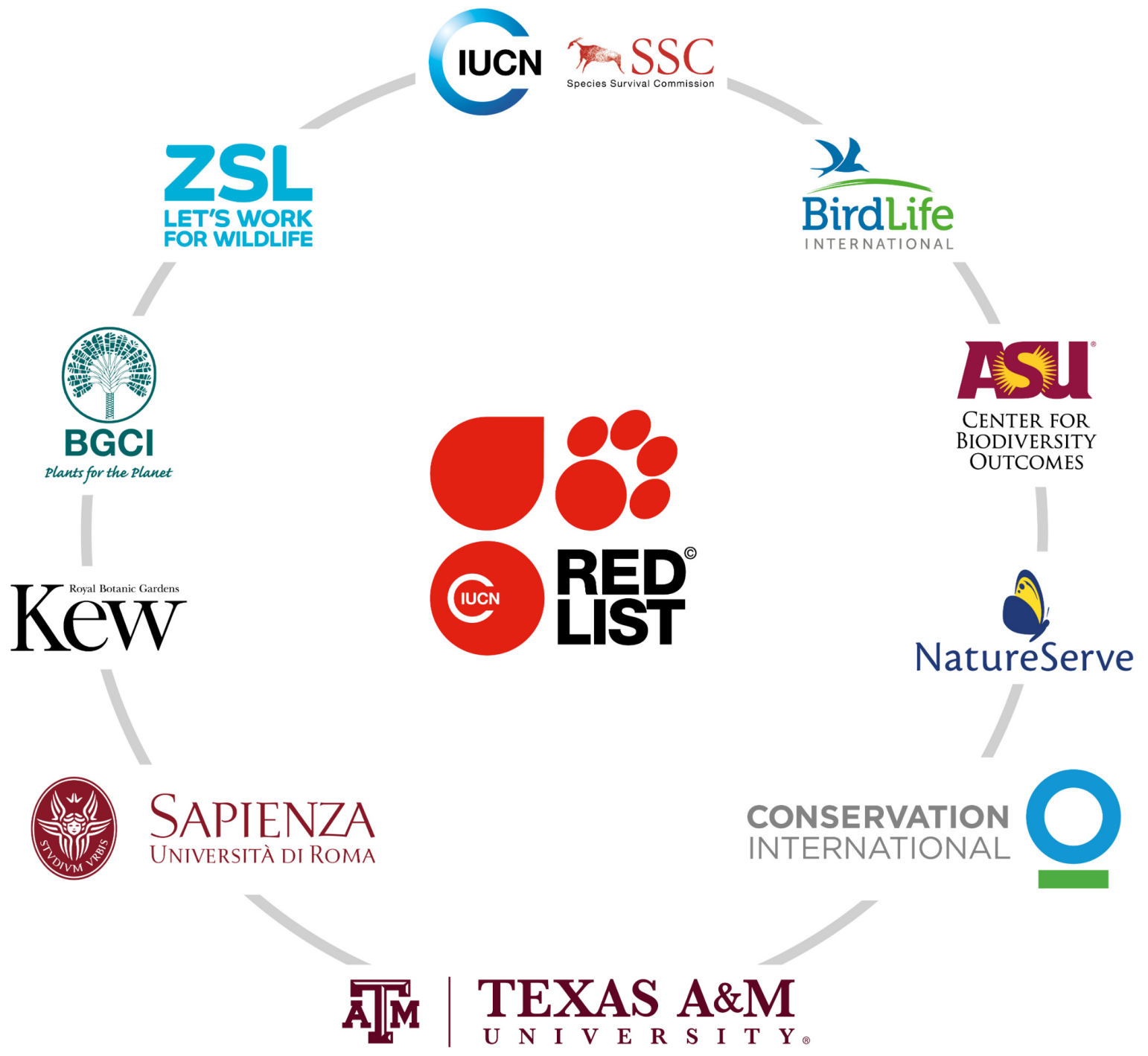

The IUCN Red List of Threatened Species ${ }^{\mathrm{TM}}$ is produced and managed by the IUCN Global Species Programme, the IUCN Species Survival Commission (SSC) and The IUCN Red List Partnership.

The IUCN Red List Partners are: Arizona State University; BirdLife International; Botanic Gardens Conservation International; Conservation International; NatureServe; Royal Botanic Gardens, Kew; Sapienza University of Rome; Texas A\&M University; and Zoological Society of London. 